\title{
Potensi Reproduksi Ikan Air Tawar Sebagai Baby Fish
}

\author{
Nuning Setyaningrum ${ }^{1}$ dan Eko Setio Wibowo ${ }^{1}$ \\ ${ }^{1}$ Fakultas Biologi, Universitas Jenderal Soedirman \\ Jalan dr. Suparno 63 Purwokerto 53122 \\ Email: nuningsetyaningrum@ymail.com
}

\begin{abstract}
The reproduction potential fish is bacic information from the phenomenon a review gonad maturation. Fish reproduction procces can see to the gonad maturation until the fish spawn and baby fish product. The research aimed to determine: (1) Fecundity, (2) Oocyts diameter; (3) Gonado Somato Index (GSI); (4) Larvae survival rate. The research materials were Cyprinus carpio, Barbonymus gonionatus, Osteochillus vittatus, Oreochromis niloticus and Clarias gariepinus. Measure parameters are fish weight, gonad weight, partial gonad weight, partial egg, oocyt diameter and life larvae. The research used experiment design, the method was a complete-ly randomized design (CRD) with 5 treatments fish species and 3 replications. The oocyt diameters was analysed descriptively and fecundity, GSI, larva survival rate were analysed by ANOVA. The result showed that fecundity and GSI accelerated at a 5 species fish $(P<0.05), B$. gonionotus had the highest fecundity on range $120.400-$ 217.150 eggs (avarage $182.320 \pm$ sd 53763,7 eggs) and O. vittatus having GSI highest at $35.13 \%$. The oocyt diameter is diffrent, $B$. Gonionotus having lowerst range $0.486-0.729 \mathrm{~mm}$ and $C$. Carpio having highest range 1,126 $-1,248 \mathrm{~mm}$ (average 1,170 $\pm \mathrm{sd} 0,067 \mathrm{~mm}$ ). $O$. niloticus larvae the best survival rate of $97 \%$, O. vittatus $93 \%$, C. carpio $77.2 \%$, C. gariepinus $51.6 \%$, B. Gonionotus $31 \%$ and Least Significant Difference larvae $O$. niloticus and $O$. vittatus has the same good survival. Reproductive potential fish O.vittatus and O.niloticus very good for developed into baby fish, based on the fecundity, oocyt diameter, gonado somato index (GSI) and larvae survival rate.
\end{abstract}

Keywords: fecundity, gonado somato index (GSI), oocyt diameter, larval surviva rate, baby fish

\begin{abstract}
Abstrak
Informasi dasar mengenai potensi reproduksi ikan dapat diperoleh dari tinjauan fenomena perkembangan gonad. Fenomena ini untuk memprediksi proses reproduksi ikan mulai dari perkembangan gonad sampai ikan memijah dan menghasilkan benih sebagai baby fish. Tujuan penelitian adalah mengetahui fekunditas, diameter telur, gonado somato index (GSI) dan kelangsungan hidup larva untuk menghasilkan baby fish. Materi penelitian adalah induk Cyprinus carpio, Barbonymus gonionatus, Osteochillus vittatus, Oreochromis niloticus dan Clarias gariepinus. Variabel adalah fekunditas, diameter telur, gonado somato index (GSI) dan kelangsungan hidup larva. Parameter yang diukur berat ikan, berat gonad,berat gonad sebagian, jumlah telur sebagian, ukuran telur dan jumlah larva hidup. Metode yang digunakan eksperimental, menggunakan metode rancangan acak lengkap (RAL) dengan perlakuan 5 spesies ikan, dengan 3 kali ulangan. Data Diameter telur dianalisis secara deskriptif dan data fekunditas, GSI, kelangsungan hidup larva dianalisis menggunakan Anova. Hasil penelitian diperoleh bahwa fekunditas dan GSI pada 5 species ikan menunjukkan perbedaan $(\mathrm{P}<0,05)$, B. gonionotus memiliki

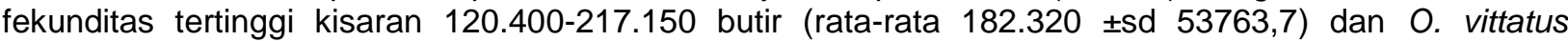
memiliki nilai GSI tertinggi 35,13\%. Diameter telur berbeda-beda pada semua spesies, B. Gonionotus memiliki diameter terkecil yaitu kisaran 0,486 - 0,729 mm (rata-rata 0,604 mm \pm sd 0,045), sedangkan

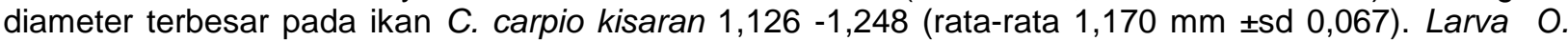
Niloticus menghasilkan presentase kelangsungan hidup terbaik sebesar $97 \%$, O. vittatus $93 \%$, C. carpio $77,2 \%$, C. gariepinus 51,6\%, B. gonionotus 31\%, berdasarkan uji Least Significant Difference (LSD), 0. niloticus dan $O$. vittatus memiliki kelangsungan hidup sama baik. Potensi reproduksi ikan $O$. vittatus dan O. niloticus sangat baik untuk dikembangkan menjadi baby fish, berdasarkan nilai fekunditas diameter telur, Gonado Somato Indeks (GSI) dan kelangsungan hidup larva.
\end{abstract}

Kata kunci: fekunditas, gonado somato index (GSI), diameter telur, kelangsungan hidup larva, baby fish 


\section{Pendahuluan}

Potensi reproduksi tiap jenis ikan berbedabeda, dapat dipengaruhi oleh campur tangan manusia, kualitas pakan dan faktor lingkungan. Potensi reproduksi ikan meliputi pola pemijahan, Indeks kematangan gonad, Fekunditas, Dimeter telur, waktu rematurasi. Beberapa ikan air tawar seperti $O$. kalabu sekerabat dengan $O$. vittatus (ikan nilem) matang gonad tiap bulan namun puncak pemijahan terjadi bulan tertentu di akhir tahun (Nasution et al., 2006). Induk ikan Puntius orphoides (ikan brek) dapat dipijahkan secara buatan menggunakan hormon sintetis (Setyaningrum \& A. Nuryanto, 2006). Ikan C.gariepinus (ikan lele dumbo) dapat dilakukan pemijahan alami ataupun semi buatan sedangkan pada C.Carpio (ikan mas) pemijahan terjadi sepanjang tahun dan tidak mengenal musim pemijahan sehingga mudah dibudidayakan. Kesiapan ikan untuk melakukan pemijahan tergantung pada tingkat kematangan gonad.

Tingkat Kematangan gonad pada ikan dapat diketahui dengan menghitung Gonado Somato Indeks (GSI), yaitu perbandingan antara berat gonad dengan berat tubuh ikan. Gonad yang semakin matang merupakan bagian dari vitellogenesis, yaitu terjadinya pengendapan kuning telur, sehingga terjadi perubahanperubahan diantaranya pertambahan berat gonad. Ikan nila yang ditemukan di waduk Golinga Ghana India memilikii nilai GSI semakin meningkat seiring dengan meningkatnya kematangan gonad sehingga terjadi peningkatan intensitas pemijahan terutama di bulan Maret dan April (Abarike ED \& A-Yeboah, 2016). Pengaruh pemberian pakan alternatif yaitu campuran antara tepung rebon, ampas tahu dan dedak dengan protein $25 \%$ dapat meningkatkan nilai Gonado Somato Indeks (GSI) pada ikan nila (Solang, 2010). Gonad yang semakin matang dapat untuk memprediksi jumlah telur yang dihasilkan (Fekunditas).

Fekunditas merupakan jumlah telur dalam ovarium sesaat sebelum dilakukan pemijahan yang dapat digunakan untuk memprediksi jumlah anakan yang akan dihasilkan. Besarnya fekunditas pada ikan dipengaruhi oleh faktor ketersediaan pakan, ukuran panjang dan berat ikan, diameter telur dan faktor lingkungan (Suzuki et al., 2000). Hasil penelitian Abarike ED and AYeboah (2016) bahwa fekunditas pada $O$. niloticus (ikan nila) berkorelasi positif dengan panjang tubuh dan berkorelasi negatif dengan berat tubuh. Semakin berat tubuh ikan nila tidak berarti semakin banyak fekunditas. Fekunditas dapat digunakan sebagai indikator jumlah larva yang dihasilkan setelah proses pemijahan, pembuahan dan penetasan telur. Fekunditas O.vittatus yang diperoleh dari danau Singkarak adalah $11.711 \pm 4.576$ butir/individu, sedangkan di sungai Antokan adalah $6.378 \pm 3.344$ butir/individu dan di waduk Koto Panjang adalah $14,824 \pm 2.397$ butir/individu (Syandri et al., 2015). Fekunditas sangat dipengaruhi oleh ukuran diameter telur.

Penyebaran diameter telur yang sudah matang dalam ovarium dapat digunakan untuk menduga frekuensi pemijahan, yaitu dengan melihat modus yang terbentuk. Waktu lama pemijahan dapat diprediksi dari ukuran diameter telur. Jika ikan tersebut memiliki waktu pemijahan yang pendek, maka semua telur yang masak di dalam ovarium akan memiliki ukuran yang sama. Namun, jika waktu pemijahan ikan tersebut lama atau terus menerus pada kisaran waktu yang lama, maka telur yang berada di dalam ovarium memiliki ukuran yang berbeda-beda (Omar, 2010). Setelah melalui tahapan pemijahan selanjutnya akan menghasilkan telur terbuahi, dan telur menetas menjadi larva.

Tahapan larva ikan masih memanfaatkan kuning telur sebagai pengganti pakan sementara, setelah kuning telur habis merupakan fase kritis sehingga perlu pakan alami atau pakan buatan yang sesuai dengan bukaan mulut larva untuk kelangsungan hidupnya. Pertumbuhan dan kelangsungan hidup larva dari berbagai jenis ikan air tawar tergantung dari pakan yang tersedia di alam sebagai pakan alami maupun pakan buatan yang sengaja dibuat serta faktor lingkungan. Larva ikan Orechromis sp dengan pakan protein $30 \%$ menghasilkan nilai retensi protein dan pertumbuhan relative meningkat (Mokoginta et al., 2005). Penelitian dengan pemberian pakan unggas, daging, tepung tulang, bungkil kedelai menghasilkan pertumbuhan yang baik pada benih C. gariepinus (Goda \& Chowdhury, 2007).

Jenis ikan air tawar yang dibudidayakan bermacam-macam jenis untuk menghasilkan ikan ukuran konsumsi. Namun masih jarang dibudidayakan untuk menghasilkan ikan konsumsii ukuran kecil yang disebut ikan lembutan (Baby Fish). Keberadaan baby fish masih sangat terbatas hanya di peroleh dari alam, sehingga perlu usaha budidaya.

Tujuan penelitian adalah mengetahui potensii reproduksi ikan air tawar meliputi fekunditas, diameter telur, gonado somato indeks (GSI) dan kelangsungan hidup larva untuk menghasilkan baby fish.

\section{Materi dan Metode}

Materi penelitian adalah induk C. carpio, $B$. gonionotus, $O$. vittatus, $O$. niloticus, $C$. gariepinus jantan dan betina Hormon sintetis merk ovaprim, pakan buatan protein $32 \%$, cacing tubifex, akuabides, Neutral Buffer Formalin (NBF). Metode penelitian yang digunakan adalah eksperimental dengan perlakuan 5 spesies ikan dan 3 ulangan. Penelitian dilakukan pada bulan Maret sampai Agustus 2014. 


\section{Pemeliharaan induk ikan}

Induk ikan dipelihara dalam kolam terpisah dan diberi pakan buatan sebanyak 3\% dari berat tubuh. Pakan diberikan 2 kali sehari.

Pengukuran diameter telur dilakukan pada waktu pemeliharaan induk ikan dengan cara kanulasii yaitu dengan memasukan selang sonde kemiringan $\pm 15^{\circ} \mathrm{C}$ kedalam lubang genetal ikan dengan diameter sesuai dengan lubang genetal masing-masing spesies ikan. Telur dari dalam ovarium di tarik menggunakan spuit masuk ke selang sonde, kemudian selang ditarik dari lubang genetal, telur dikeluarkan dan dimasukkan dalam botol sampel yang diberi larutan Netral Buffer Formalin (NBF) untuk mengawetkan telur.

Pengamatan diameter telur dilakukan dengan cara mengambil sebanyak 50 butir kemudian diamatii dibawah mikroskup dilengkapi dengan mikrometer okuler dan dicatat ukuran diameter telur menggunakan rumus (Effendie, 1979):

Pengukuran diameter ovum = jumlah skala okuler dikalikan angka kalibrasi.

Mencari nilai 1 okuler pada skala obyektif:

$$
1 \text { okuler }=\frac{\sum \text { obyektif }}{\sum \text { okuler }} \text { xobyektif }
$$

\section{Pengukuran Fekunditas}

Pengukuran fekunditas dilakukan dengan cara menimbang berat induk sebelum memijah dan berat induk ikan setelah memijah, untuk mendapatkan nilai berat gonad yaitu selisih berat induk ikan sebelum memijah dan sesudah memijah. Induk betina dinduksi dengan hormon sintetis merk ovaprim dan siap untuk memijah, kemudian dilakukan striping sebelum dicampur dengan sperma, telur diambil sebagian (1-2\%) untuk perhitungan nilai berat gonad dan jumlah telur sebagian untuk menghasilkan nilai fekunditas. Nilai yang diperoleh dimasukkan dengan rumus (Seifali \& Esmaeili, 2012).

Keterangan:

$$
\mathrm{F}=\mathrm{Fs} \times \frac{G W}{G W S}
$$

$\mathrm{F}=$ Fekunditas

$\mathrm{Fs}=$ jumlah telur sebagian

$\mathrm{GW}=$ berat gonad

GWs = berat gonad sebagian

\section{Pemijahan Buatan}

Setelah induk ikan mencapai tingkat kematangan gonad tahap akhir yaitu ditandai dengan ukuran diameter telur yang sudah seragam dan ukuran maksimal, pada ikan $O$. vittatus mencapai ukuran diameter $1,1 \mathrm{~mm}$. Induksi hormon sintetis merk ovaprim dengan dosis $0,5 \mathrm{ml} / \mathrm{kg}$ berat ikan dilakukan untuk mempercepat ovulasi dengan cara injeksi pada bagian belakang sirip punggung ikan betina dan jantan. Selanjutnya induk ikan betina dan jantan dimasukan dalam kolam yang berbeda dan ditunggu sekitar 8-12 jam sebagai waktu laten. Ikan jantan dan betina di striping (pengurutan) pada bagian perut, kemudian telur dan sperma dicampur dalam baskom dengan digoyanggoyang kemudian dimasukkan kedalam 3-6 akuarium tergantung banyaknya telur. Telur terbuahi berwarna transparan sedangkan telur tidak terbuahi dalam waktu 6 jam akan berwarna putih keruh, telur yang sudah terbuahi akan mengembang hingga 3-5 dari diameter telur awal (Setyaningrum \& Nuryanto, 2006).

\section{Pengamatan Gonado Somato Index (GSI)}

Induk ikan betina sebelum memijah dan sesudah memijah ditimbang berat tubuhnya untuk menentukan berat gonad (Subagja, 2006). Berat gonad diperoleh dengan berat tubuh ikan sebelum memijah dikurangi berat tubuh sesudah memijah. Menghitung IGS menggunakan rumus (Abarike \& Yeboah, 2016) :

Gonado Somato Indeks $(\mathrm{GSI})=\frac{\text { Berat Gonad }}{\text { Total Berat Tubuh }} \times 100$

\section{Pengamatan Kelangsungan Hidup Larva}

Kelangsungan hidup larva menunjukkan persentase larva yang hidup sampai dengan umur 12 hari. Larva diberi pakan cacing tubifex dan dihitung ikan yang mati. Tingkat kelangsungan hidup larva dihitung dengan rumus (Effendie 1997) :

$$
\operatorname{SR}(\%)=\frac{N t}{N o} \times 100 \%
$$

Keterangan

SR=Tingkat kelangsungan hidup larva (\%)

$\mathrm{Nt}=$ Jumlah larva hidup

$\mathrm{No}=$ Jumlah larva seluruhnya

\section{Metode Analisis}

Nilai diameter telur dan hasil pemijahan induk ikan dianalisis secara deskriptif. Nilai Fekunditas, IGS dan Kelangsungan hidup larva dianalisis secara statistik dengan Analisis Variansi (Anova) menggunakan Software SPSS 19. Bila terjadii perbedaan antar perlakuan dilanjutkan dengan uji Least Significant Difference (LSD).

\section{Hasil dan Pembahasan}

Induk ikan C. carpio, B. gonionotus, $O$. vittatus, $O$. niloticus, $C$. Gariepinus berhasil melakukan pemijahan buatan pada kolam pemijahan dengan waktu laten berkisar antara 8 sampai 12 jam. Waktu laten merupakan waktu saat pertama kali ikan diinjeksi dengan hormon sintetis sampai dengan ikan jantan mengeluarkan sperma dan ikan betina mengeluarkan telur untuk kemudian terjadi fertilisasi eksternal. Pemijahan buatan yang dilakukan pada ikan brek menghasilkan waktu laten 10 jam (Setyaningrum \& Nuryanto, 2006). 
Pengamatan fekunditas pada lima spesies induk ikan menunjukkan hasil $B$. gonionotus memiliki nilaii tertinggi rata-rata $182.320 \pm$ sd 53763,7 butir dan terendah $O$. niloticus rata-rata $1.898 \pm$ sd 103,5 butir (gambar 1). Nilai fekunditas pada lima spesies ikan air tawar disajikan pada gambar 1.

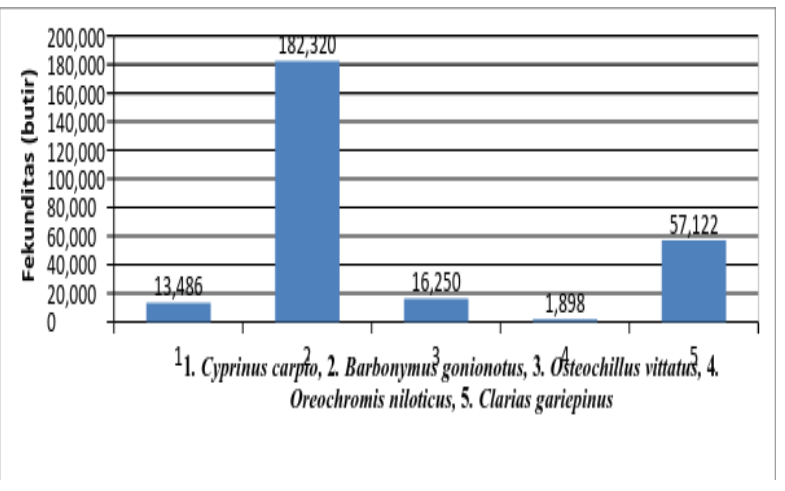

Gambar 1. Fekunditas lima spesies ikan air tawar

Kisaran nilai fekunditas tertinggi sampai dengan terendah adalah $B$. gonionotus (ikan tawes) 120.400-217.150 butir, selanjutnya $C$. Gariepinus (ikan lele dumbo) 51.400-60.000 butir, O.vittatus (ikan nilem) 15.000-17.250 butir, $C$. Carpio (ikan mas) 12.000-15.260 butir dan $O$. niloticus (ikan nila) 1.780-1970 butir. Berdasarkan analisis Anova menggunakan SPSS 19 nilai fekunditas menunjukkan perbedaan terhadap lima spesies $(P<0,05)$. B. gonionotus menghasilkan fekunditas tertinggi, hasil ini berhubungan dengan ukuran diameter telur yang tergolong kecil yaitu rata-rata 0,604 \pm sd 0,045 $\mathrm{mm}$ dibandingkan 4 spesies lain yang memiliki diameter lebih besar. Selain itu B. gonionotus memiliki rongga bagian abdomen yang luas untuk mengisi telur. Effendie (1997) menyatakan diameter telur berhubungan dengan fekunditas, semakin besar diameter telur maka fekunditas semakin kecil untuk semua ikan. Fekunditas P.orphoides yang sekerabat dengan $B$. gonionotus memiliki fekunditas berkisar 7.379 39.794 butir, sehingga hasil peneltian ini B.gonionutus lebih tinggi dari P.orphoides (Suryaningsih et al., 2014).

C.gariepinus tergolong memiliki fekunditas tinggi yaitu $51.400-60.000$ butir setelah B.gonionotus dan berpotensi untuk menghasilkan anakan yang banyak. Hasil ini lebih rendah dibandingkan ikan lele dumbo mutiara dengan fekunditas $72.700-165.900$ butir $/ \mathrm{kg}$ bobot induk (rata-rata $102.400 \pm 25.000$ butir $/ \mathrm{kg}$ bobot induk) (Iswanto et al., 2016). O.vittatus termasuk satu familia dengan ikan tawes tetapi memiliki fekunditas lebih kecil yaitu 15.000-17.250 butir dan hasil ini berbeda dengan penelitian Omar (2010) ikan nilem memiliki fekunditas berkisar 1.718-34.045 butir, C.carpio dengan kisaran fekunditas 12.000-15.260 butir, hasil ini lebih rendah dari penelitian Ardiansyah et al., (2016) fekunditas ikan mas memiliki kisaran 15.00017.250 butir. Sedangkan fekunditas O.niloticus yaitu kisaran 1.780-1970 butir terendah dari penelitian ini, karena memiliki sifat Mouth breeder yaitu mengerami telur dan larva ikan di dalam mulut sehingga jumlah telur terbatas dan memiliki diameter telur lebih besar dari ikan $B$. gonionotus. Hasil ini hampir sama dengan hasil penelitian Ardiansyah at al., (2016) bahwa fekunditas O.niloticus dengan kisaran 1.738-5.203 butir (ratarata 3.317 butir). Namun hasil fekunditas ini lebih tinggi dari O.niloticus yang ditemukan di Golinga Ghana kisaran 137 - 250 butir (Abarike \& Yeboah, 2016). Ikan yang dipelihara pada tempat yang berbeda menghasilkan nilai fekunditas yang berbeda karena dipengaruhi oleh makanan yang tersedia dan kualitas air. Sesuai dengan pernyataan Oliveira et al., (2015), bahwa fekunditas dipengaruhi oleh ketersediaan pakan di alam dan lingkungan tempat hidup serta ukuran tubuh.. Fekunditas berkaitan erat dengan ukuran diameter telur didalam ovarium ikan,, kisaran ukuran diameter telur disajikan pada tabel 1 .

Tabel 1. Diameter telur ( $\mathrm{mm}$ ) lima spesies ikan air tawar pada minggu ke 4 pemeliharaan

\begin{tabular}{lcccc}
\hline \multirow{2}{*}{ Jenis ikan } & \multicolumn{3}{c}{ Ulangan } & \multirow{2}{*}{ Rata-rata } \\
\cline { 2 - 4 } & 1 & 2 & 3 & \\
\hline Cyprinus carpio & 1,134 & 1,248 & 1,126 & $1,170 \pm$ sd 0,067 \\
Barbonymus gonionotus & 0,603 & 0,559 & 0,650 & $0,604 \pm$ sd 0,045 \\
Osteochillus vittatus & 0,939 & 0,905 & 0,936 & $0,926 \pm$ sd 0,018 \\
Oreochromis niloticus & 0,972 & 0,904 & 0,816 & $0,897 \pm$ sd 0,078 \\
Clarias gariepinus & 0,975 & 1,033 & 0,936 & $0,981 \pm s d 0,048$
\end{tabular}


Diameter telur lima spesies ikan berbedabeda ukurannya. Ukuran diameter telur dari yang terbesar sampai dengan terkecil yaitu pada $C$. carpio rata-rata $1,170 \pm \mathrm{sd} 0,067 \mathrm{~mm}$ (kisaran 1,126-1,248 mm), C.gariepinus yaitu rata-rata 0,981 $\pm \mathrm{sd} 0,048 \mathrm{~mm}$ (kisaran 0,936-1,033), selanjutnya $O$. vittatus yaitu rata-rata $0,926 \pm$ sd 0,018 mm (kisaran 0,905-0,939 mm), O.niloticus yaitu rata-rata $0,897 \pm s d 0,078 \mathrm{~mm}$ (kisaran 0,816 $0,972 \mathrm{~mm})$ dan diameter terkecil pada $B$. gonionotus rata-rata $0,604 \pm s d 0,045 \mathrm{~mm}$ (kisaran 0,559-0,650 mm).

Ukuran diameter telur pada C.carpio terbesar dibandingkan dengan 4 spesies ikan penelitian ini. Ukuran diameter telur yang besar biasanya bersifat adhesif yaitu telur setelah dipijahkan akan menempel pada substrat. Diameter telur 0,8-1,6 $\mathrm{mm}$ pada carp selain siap untuk memijah dapat dimanfaatkan sebagai caviar (Kathiravelu at al., 2003). Sedangkan ukuran diameter telur terkecil terdapat pada B.gonionotus. Ikan yang memiliki diameter kecil akan memiliki fekunditas tinggi. Pada minggu ke empat pemeliharaan memiliki diameter telur siap memijah terutama O.vittatus yaitu $1,222 \mathrm{~mm}$, sedangkan $C$. gariepinus, $C$. carpio dan $O$. niloticus ukuran diameter telur cenderung lebih besar dari O.vittatus dan $B$. Gonionotus keduanya siap memijah. Kathiravelu et al., (2003) menyatakan kisaran diameter telur yang bervariasi dimungkinkan akibat adanya perbedaan tingkat kematangan gonad yang dimiliki tiap jenis ikan. Perbedaan tingkat kematangan gonad tersebut sebagai akibat terjadinya proses vitellogenesis atau pengendapan kuning telur, hidrasi dan pembentukan butir-butir minyak yang berjalan secara bertahap. Diameter telur yang hampir seragam dapat untuk menentukan kapan ikan akan melakukan proses pemijahan. Penelitian Seifali \& Esmaeili (2012) pada Alburnoides sp in South Caspian from Iran, diperoleh diameter telur ukuran besar di bulan April dan Mei, diameter telur ukuran kecil di bulan Agustus sehingga disimpulkan musim memijah selama bulan JuniJuli. Ukuran diameter telur tiap bulan dapat untuk menentukan sifat pemijahan apakah partial spawner yaitu hanya sebagian telur yang di keluarkan saat memijah atau total spawner yaitu semua telur dikeluarkan saat memijah dan dalam waktu singkat (Oliveira et al., 2015). Ikan sudah siap memijah di tandai dengan meningkatnya nilai gonado somato indeks (GSI). Pengukuran nilai
GSI pada lima spesies ikan disajikan pada gambar 2.

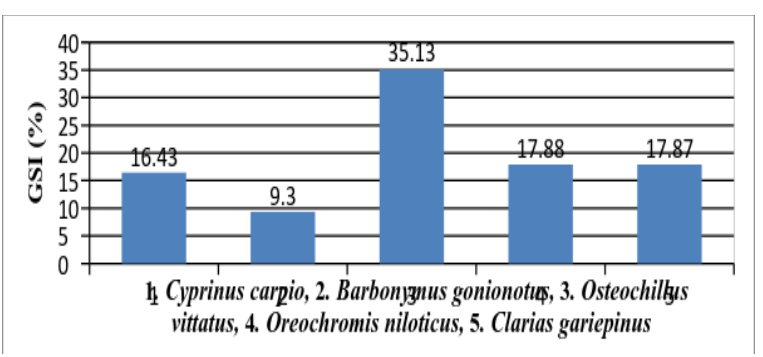

Gambar 2. Nilai GSI lima spesies ikan air tawar

Nilai GSI dari yang tertinggi sampai dengan terendah adalah $O$. vittatus rata-rata $35,13 \pm$ sd $1,67 \%$, O. niloticus rata-rata $17,88 \pm$ sd $1,04 \%$, selanjutnya C.gariepinus rata-rata $17,87 \pm$ sd $1,80 \%$, C.carpio rata-rata $16,43 \pm$ sd $0,64 \%$ dan B.gonionitus rata-rata $9,3 \pm$ sd $0,44 \%$. O. vittatus memiliki nilai IGS tertinggi yang menunjukkan bahwa proses kematangan gonad lebih cepat dibandingkan dengan 4 spesies ikan lain. Berdasarkan uji Anova menggunakan SPSS 19 nilai GSI menghasilkan perbedaan terhadap lima spesies ikan $(P<0,05)$ dan $O$. vittatus tertinggi. Hasil ini menunjukkan bahwa O.vittatus melakukan pemijahan musiman. Sesuai dengan pendapat Cholik (2005) yaitu GSI suatu jenis ikan akan semakin meningkat nilainya dan mencapai maksimum pada saat terjadi pemijahan dan akan menurun secara bertahap dengan berakhirnya musim pemijahan. Lebih lanjut dikatakan bahwa sifat pemijahan ikan dapat dilihat dari nilai GSI nya yaitu jika GSI < 20\% maka ikan tersebut memijah sepanjang tahun sedangkan jika nilai GSI > 20\% ikan tersebut memijah per musim. Nilai GSI ikan nilem penelitian ini lebih tinggi dari ikan nilem yang ditemukan di danau Sindenreng Sulawesi Selatan yaitu rata-rata rata-rata 11,22 $\mathrm{sd} \pm 4,94 \%$ pada TKG IV sehingga pemijahan bersifat sepanjang tahun (Omar,, 2010). O.niloticus nilai GSI 17,88\% hasil ini lebih tinggi dari yang ditemukan di danau Paniai Papua yaitu rata-rata $1,47 \%$ dan memijah sepanjang tahun. Menurut Ghufran (2010), ikan nila memilikii kemampuan untuk melakukan pembuahan yang sangat tinggi. Jarang sekali ada telur yang gagal terbuahi. Ikan C.gariepinus, C.carpio dan B.gonionotus nilai GSI kurang dari $20 \%$ sehingga tergolong ikan yang memijah sepanjang tahun. Hasill nilai GSI pada penelitian ini semua spesies ikan sudah siap memijah. Nilai GSI sebesar $6,88 \%$ dapat digunakan sebagai indikator kematangan gonad dan siap memijah pada ikan Alburnoides sp sejenis ikan mas yang di temukan di sungai Kesselian Iran Utara. Rerata nilai GSI tiap bulan dan ukuran diameter telur menunjukkan bahwa ikan tersebut bertelur sekali 
dalam setahun selama bulan Juni-Juli (Seifali \& Esmaeili, 2012).

Kelangsungan hidup larva lima spesies ikan air tawar penelitian ini menunjukkan hasil bervariasi selama 12 hari pemeliharaan. Kelangsungan hidup larva tertinggi sampai terendah yaitu $O$. niloticus rata-rata $97,0 \%, O$. vittatus rata-rata $93,8 \%$ selanjutnya $C$.carpio ratarata $77,2 \%$, C. Gariepinus $51,6 \%$ dan terendah B. gonionotus rata-rata $31,0 \%$. Kelangsungan hidup larva lima jenis ikan di sajikan pada gambar 3.

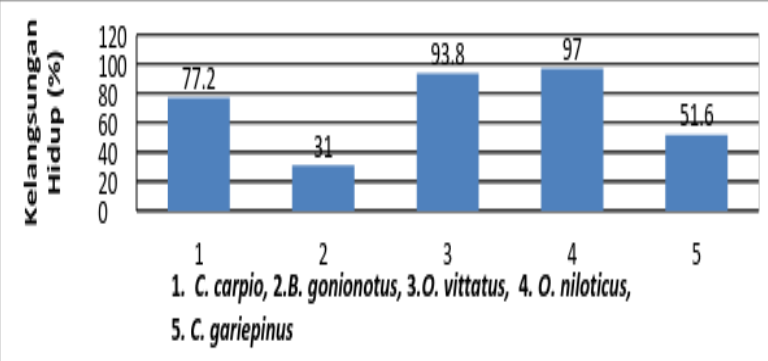

Gambar 3. Prosentase Kelangsungan Hidup Larva Lima Spesies Ikan Air Tawar

Kelangsungan hidup larva tertinggi pada O.niloticus dan terendah pada B.gonionotus. Berdasarkan uji Anova menggunakan SPSS 19 diperoleh larva $O$. niloticus menghasilkan kelangsungan hidup terbaik rata-rata $97 \%$. Uji lanjut dengan Least Significant Defference (LSD) diperoleh larva $O$. niloticus dan $O$. vittatus memiliki kelangsungan hidup sama baik, sehingga berpotensi dikembangkan sebagai baby fish. Baby fish merupakan benih ikan yang dihasilkan dari proses pemijahan, pembuahan sampai dengan pendederan berupa benih ikan ukuran tertentu. Hasil kelangsungan hidup larva $O$. niloticus rata-rata $97 \%$ sesuai yang dilakukan oleh Dinas Perikanan dan kelautan Sulawesi Tengah larva ikan $O$. niloticus memiliki kelangsungan hidup dari telur menjadi benih (ukuran $<5$ gram) dapat mencapai $70-90 \%$. $O$. niloticus mempunyai pertumbuhan cepat, rataan pertumbuhan harian mencapai 4,1 gram/hari (Departemen Perikanan dan Kelautan, 2010). O. vittatus di pelihara hanya berupa produk sampingan dari hasil budidaya ikan secara polikultur sehingga $O$. vittatus dapat lebih ekonomis sampai ukuran 5 gram/ekor sebagai baby fish. Kelangsungan hidup larva $O$. vittatus $93,8 \%$ hasil ini lebih baik dari penelitian (Subagja et al., 2011) dengan kelangsungan hidup $77 \%$. Kelangsungan hidup larva $O$. niloticus dan $O$. vittatus yang baik ini mampu memanfaatkan pakan yang diberikan, sehingga mampu menghasilkan energi yang dibutuhkan untuk aktivitas tubuh. Jenis ikan ini dapat dibudidayakan sebagai baby fish untuk diversifikasi usaha sehingga tidak membutuhkan waktu lama pemeliharaan dan biaya operasional rendah serta dapat di lakukan pada lahan sempit.Sedangkan untuk B.goionotus memiliki nilai kelangsungan hidup terendah hasil ini tergolong rendah karena kurang dari $50 \%$.

Potensi reproduksi pada 5 spesies ikan yaitu C.carpio, B.gonionotus, C.vittatus, O.niloticus dan C.gariepinus meliputi fekunditas, diameter telur, Gonado Somato Indeks (GSI) dan kelangsungan hidup larva. Fekunditas tertinggi terdapat pada ikan B.gonionotus sehingga berpeluang untuk menghasilkan larva yang banyak, namun memilikii tingkat kelangsungan hidup rendah. Spesies ikan yang berpeluang untuk memilki fekunditas tinggi dan kelangsungan hidup tinggi adalah O.vittatus. Diameter telur pada 5 spesies ikan berhubungan dengan fekunditasnya semakin besar diameter telur maka fekunditas semakin kecil. Keseragaman ukuran diameter telur dapat menentukan sifat pemijahan apakah tergolong partial spawner atau total spawner. Ke 5 spesies ikan memiliki ukuran diameter yang hampir seragam sehingga pemijahan bersifat total spawner. Gonado Somato Indeks (GSI) dapat untuk menentukan ikan memijah sepanjang tahun atau memijah per musim. Ikan C.carpio, B.gonionotus, O.niloticus dan C.gariepinus pemijahannya terjadi sepanjang tahun sedangkan O.vittatus pemijahannya tergantung pada musim. Kelangsungan hidup yang baik terdapat pada ikan O.niloticus dan O.vittatus sehingga berpeluang dikembangkan menjadi baby fish.

\section{Simpulan}

Berdasarkan uraian diatas dapat disimpulkan bahwa potensi reproduksi ikan $O$. vittatus dan $O$. niloticus sangat baik untuk dikembangkan menjadi ikan konsumsi baby fish, berdasarkan nilai fekunditas diameter telur, Gonado Somato Indeks (GSI) dan kelangsungan hidup larva. Terutama $O$. vittatus agar menjadi lebih ekonomis perlu dilakukan budidaya secara intensif pada tahapan pembenihan sampai dengan ukuran 5 g/ekor, sebagai diversifikasi usaha dengan menghasilkan baby fish.

\section{Ucapan Terima Kasih}

Penelitian ini dapat terlaksana karena di danai oleh dana penelitian Desentralisasi Badan Layanan Umum (BLU) Universitas Jenderal Soedirman tahun anggaran 2014. Penulis mengucapkan terimakasih kepada Rektor Unsoed atas dana yang diberikan dan Ketua Lembaga Penelitian dan Pengabdian Kepada Masyarakat yang telah menseleksi proposal penelitian Hibah bersaing 


\section{Daftar Referensi}

Abarike ED and A-Yeboah. 2016. "Reproductive Potential of Nile Tilapia ( Oreochromis Niloticus Linnaeus , 1757 ) in the Golinga Reservoir in Ghana." 4(5): 279-83.

Ardiansyah,V., Samuel., Y.C. Ditya., D.P. Mentari., Mersi., $\quad$ M. Gobai. 2016. Karakteristik Habitat, Potensi, dan Biologi Ikan di Danau Paniai Papua. Balai Penelitian Perikanan Perairan Umum. Kementerian Kelautan dan Perikanan.

Cholik, F., R. P. Poernomo \& A. Jauzi. 2005. Aquakultur: Tumpuan Harapan Masa Depan Bangsa Masyarakat Perikanan Nusantara dan Taman Akuarium Air Tawar - TMII, Jakarta.

Departemen Perikanan dan Kelautan. 2010. "Petunjuk Teknis Pembenihan dan Pembesaran Ikan Nila Oreochromis Niliticus."Dinas Perikanan dan Kelautan Daerah Provinsi Sulawesi Tengah.

Goda, A. M, and M. A. K. Chowdhury. 2007. "Effect of Totally or Partially Replacing Fish Meal by Alternative Protein Sources on Growth of African Catfish Clarias Gariepinus (Burchell , 1822 ) Reared in Concrete Tanks." Aquaqulture Research 38:279-287.

Iswanto,B., R. Suprapto., H. Marnis., dan Imron. 2016. Performa Reproduksi Ikan Lele Mutiara (Clarias gariepinus) Media Akuakultur, 11 (1),: 1-9.

Kathiravelu, PS., P. Brown., D, Stoessel and A, Giles. 2003. "Maturation and Reproductive Biology of Female Wild Carp , Cyprinus Carpio , in Victoria , Australia." Environmmental Biology of Fishes (68): 32132.

Mokoginta, I., S. Vemmi., N. Bambang dan P. Utomo. 2005. "Pengaruh Kadar Kromium Pakan Yang Berbeda Terhadap Retensi Protein, Pertumbuhan dan Kesehatan Ikan Nila, Oreochromis Niloticus" Jurnal ilmu-ilmu Perairan dan Perikanan Indonesia 12(1): 3337.

Nasution,N dan S.N. Hasibuan S. 2006. "Potensi Akuakultur Ikan Kelabau (Osteochilus kelabau) Dari Perairan Kabupaten Pelalawan
Propinsi Riau: Siklus Reproduksi." Prosiding Seminar Nasional Ikan IV: 29-30.

Oliveira., MR, Silva, NB., Yamamoto, ME and Chellappa, S. 2015. "Gonad Development and Reproduction of the Ballyhoo Half Beak, Hemiramphus brasiliensis from the Coastal Waters of Rio Grande Do Norte , Brazil." Braz.J. Biol 75(2): 324-30.

Omar, S.A. 2010. "Aspek Reproduksi Ikan Nilem, Osteochilus Vittatus ( Valenciennes, 1842 ) Di Danau Sidenreng , Sulawesi Selatan Jurnal Iktiologi Indonesia." Jurnal Iktiologi Indonesia 10(2): 111-22.

Setyaningrum, N dan A. Nuryanto. 2006. "Penjinakan Dan Budidaya Ikan Brek (Puntius Orphoides) Sebagai Upaya Menuju Diversifikasi Usaha Tani Ikan." Jurnal Pembangunan Pedesaan 6(1): 25-31.

Seifali, M., A. Arshad, and H. R. Esmaeili. 2012. "Fecundity and Maturation of South Caspian Spirlin, Alburnoides Sp . ( Actinopterygii : Cypriniade ) from Iran." Iranian Journal of Science \& Technology A2: 181-187.

Solang, M. 2010. "Indeks Kematangan Gonad Ikan Nila (Oreochromis Niloticus L) Yang Diberi Pakan Alternatif dan Dipotong Sirip Ekornya." Saintek 5(2).

Subagja, J., L. Setijaningsih dan R. Gustiano. 2011. "Prosiding Forum Inovasi Teknologi Akuakultur 2011." Prosiding Forum Inovasi Teknologi Akuakultur: 1171-1176.

Suryaningsih, S., M. Sagi, H. N. Kamiso dan S. Hadisusanto. 2014. "Sexing Pada Ikan Brek Puntius Orphoides ( Valenciennes , 1863 ) Menggunakan Metode Truss Morfometrics. Biosfera, 31(1): 8-16

Suzuki. H.I., A.A. Agostinho and K.O. Winermiller. 2000. "Relationship between Oocyte Morphology and Reproductive Strategy in Loricariid Catfishes of the Parana' River , Brazil." Journal of Biology 1(57): 791-807.

Syandri, H., Azrita and Junaidi. 2015. "Fecundity of Bonylip Barb (Osteochilus Vittatus Cyprinidae) in Different Waters Habitats." International Journal of Fisheries and Aquatic Studies 2015; 2(4): 157-163. 